\title{
AVALIAÇÃO DA SEGURANÇA MICROBIOLÓGICA DAS LUVAS DE LÁTEX PARA PROCEDIMENTOS EM UMA UNIDADE DE TERAPIA INTENSIVA ${ }^{a}$
}

\section{Resumo}

Introdução: a utilização de luvas de látex para procedimentos é essencial nas atividades que envolvem risco biológico no cuidado à saúde; no entanto, ainda é controversa a segurança microbiológica das luvas de procedimento, considerando sua exposição ambiental. Objetivos: quantificar as Unidades Formadoras de Colônias (UFC) das luvas de látex para procedimentos em momentos distintos (início, meio e fim das caixas) na situação real e controle de enluvamento; avaliar a contaminação das luvas conforme o tempo de exposição ambiental das caixas; isolar o microrganismo mais freqüente e determinar o perfil de sensibilidade aos antibióticos. Material e Método: trata-se de um estudo comparativo e prospectivo realizado em uma unidade de terapia intensiva de um hospital-escola. Após aprovação do comitê de ética em pesquisa, procedeuse à coleta das amostras microbiológicas das luvas de látex por meio da digitopressão em placas de Petri, preparadas com meio de cultura Mueller Hinton (MH). Esse procedimento foi realizado em 31 caixas de luvas de látex para procedimentos em diferentes momentos (início, meio e fim das caixas) e em situação real de enluvamento e controle. 0 Etest $^{\circledR}$ foi utilizado na determinação do perfil de sensibilidade aos antibióticos (Ciprofloxacina ${ }^{\circledR}$, Oxacilina $^{\circledR}$, Cefepime $^{\circledR}$, Gentamicina $^{\circledR}$, Amicacina ${ }^{\circledR}$ e Vancomicina ${ }^{\circledR}$ ). Os dados foram submetidos à análise estatística por meio do Teste de Cochran e Spearman, considerando nível de significância de á=0,05. Para comparação do número de UFC, realizou-se análise de variância (ANOVA) com medidas repetidas. Resultados: totalizaram-se 372 placas de Petri, das quais 186 foram obtidas na situação real de enluvamento e 186 no controle. A média de UFC foi de 4,7, na situação controle, e de 6,2 na situação real de enluvamento, não demonstrando diferenças estatisticamente significantes $(p=0,601)$. Em relação à avaliação dos pares de luvas no início, meio e fim da caixa na situação real de enluvamento e controle, não foram evidenciadas diferenças significantes no crescimento microbiano (UFC). $\mathrm{Na}$ associação entre o tempo de abertura ao término da caixa de luvas e o número de UFC, tanto na situação real de enluvamento quanto no controle, não houve correlação $(p=0,63)$. Quanto aos microrganismos, a bactéria Staphylococcus spp. foi a mais freqüente. Com relação ao perfil de sensibilidade, 13 cepas $(24,8 \%)$ apresentaram resistência a pelo menos dois antibióticos; destas, $3(5,5 \%)$ tiveram resistência à vancomicina. Conclusão: os resultados corroboraram a hipótese inicial da pesquisa quanto à segurança microbiológica das luvas de látex para procedimentos considerando os baixos valores de UFC.

Palavras-chave:

Luvas Protetoras. Infecção Hospitalar. Staphylococcus. Unidades de Terapia Intensiva. Resistência a Drogas. 


\title{
EVALUATION OF THE MICROBILOGIC SECURITY OF THE LATEX GLOVES FOR THE PROCEDURES IN AN INTENSIVE TERAPY UNIT
}

\begin{abstract}
Introduction: the use of latex gloves is essential and unquestionable in activities that involve biological risk in the health care. However, it is still controversial the microbiological safety of gloves for procedures considering their environmental exposition. Objectives: quantify the Colony-Forming Units (CFU) of latex gloves for procedures in different moments (beginning, middle and end of boxes) in real situation and gloving control; evaluate the contamination of gloves regarding the boxes time of environmental exposition; isolate the most frequent microorganism and determine the sensibility profile to antibiotics.

Material and Method: It is a comparative and prospective study performed in an intensive therapy unit of a school hospital. After approval of the committee of ethics in research the collection of microbiological sample of latex gloves through digital pressure in Petri plaques prepared with culture media Mueller Hinton (MH) was initiated. This procedure was performed in 31 latex gloves boxes for procedures in different moments (beginning, middle and end of boxes) and, in real gloving and control situations. The Etest $\circledast$ was used to determine the sensibility profile of antibiotics (Ciprofloxacin $\AA$, Oxacillin $\AA$, Cefepime $®$, Gentamicin $\AA$, Amikacin $\AA$ e Vancomycin $®$ ). The data was statistically analyzed through the Cochran and Spearman test considering a level of significance of $a=0,05$. Analysis of variance (ANOVA) with repetitive measures was used for the comparison of number of CFU. Results: a total of 372 Petri plaques were obtained, 186 in real gloving situation and 186 in the control situation. The CFU average was 4,7 in the control situation, and 6,2 in the real gloving situation, with no statistically significant differences $(p=0,601)$. There was no evidence of significant differences in the microbial growth (CFU) in the evaluation of gloves pairs in the beginning, middle and end of boxes in both the real and control situations. There was no correlation $(p=0.63)$ in the association between time of opening and finishing the box of gloves with the number of CFU, both in the real and control situations. The Staphylococcus spp. was the most frequent microorganism. Regarding the sensibility profile, 13 strains $(24.8 \%)$ were resistant to at least two antibiotics; from these three $(5.5 \%)$ resisted Vancomycin $®$. Conclusion: The results obtained support the initial hypothesis regarding the microbiological safety of latex gloves for procedures considering the low levels of CFU.
\end{abstract}

Keywords: Gloves. Protective. Cross infection. Staphylococcus. Intensive care units. Drug Resistance. 


\section{EVALUACIÓN DE LA SEGURIDAD MICROBIOLOGICA DE LAS GUANTES DE LATEX PARA PROCEDIMIENTOS EN UNA UNIDAD DE TERAPIA INTENSIVA}

\section{Resumen}

Introducción: La utilización de guantes de látex para procedimientos es incuestionablemente esencial en las actividades que envuelven riesgo biológico en el cuidado de la salud. Sin embargo, aún es polémico su uso especialmente en lo que se refiere a la seguridad microbiológica del inicio al final de la caja. Objetivos: cuantificar las Unidades Formadoras de Colonias (UFC) de los guantes de látex para procedimientos en momentos distintos (inicio, medio y final de las cajas) en la situación real y control de colocación; evaluar la contaminación de los guantes en función del tiempo de exposición ambiental de las cajas; aislar el microorganismo más frecuente y determinar el perfil de la sensibilidad a los antibióticos. Material y Método: se trata de un estudio comparativo y prospectivo, realizado en una unidad de terapia intensiva de un hospital universitario. Después de ser aprobado por el comité de ética en investigación se procedió a recolección de las muestras microbiológicas de los guantes de látex por medio de la digito-presión en placas Petri preparadas con medio de cultura Mueller Hinton (MH). Este procedimiento fue realizado en 31 cajas de guantes de látex para procedimientos en diferentes momentos (inicio, medio y fin de las cajas) y, en situación real de colocación y control. El Etest ${ }^{\circledR}$ fue utilizado en el antibiograma com Ciprofloxacina ${ }^{\circledR}$, Oxacilina ${ }^{\circledR}$, Cefepime ${ }^{\circledR}$, Gentamicina ${ }^{\circledR}$, Amicacina $^{\circledR}$ y Vancomicina ${ }^{\circledR}$. Los datos fueron sometidos a análisis estadísticos por medio del Test de Cochran y Spearman considerando nivel estadisticamente significante á $=0,05$. Para la comparación del número de UFC se realizó el análisis de variancia (ANOVA) de medidas repetidas. Resultados: se totalizó 372 placas de Petri siendo 186 obtenidas en la situación real de colocación del guante y 186 en el control. La media de UFC en la situación control fue de 4,7 y 6,2 en la situación real de colocación del guante, no mostrando diferencias estadisticamente significantes $(p=0,601)$. En relación a la evaluación de los pares de guantes en el inicio, medio y fin de la caja en situación de colocación y control no se evidenciaron diferencias significativas en el crecimiento microbiano (UFC). No se encontró asociación $(p=0,63)$ entre el tiempo de abertura al término de la caja de guantes con el número de UFC, tanto en la situación de colocación del guante como en el control. En relación a los microorganismos el agente Staphylococcus ssp fue el más frecuente. En relación al perfil de sensibilidad 13 cepas $(24,8 \%)$ presentaron resistencia a por lo menos 2 antibióticos; de esas 3 (5,5\%) tuvieron resistencia a Vancomicina. Conclusión: los resultados obtenidos corroboraron la hipótesis inicial de la investigación cuanto a la seguridad microbiológica de los guantes de látex para procedimientos considerando los bajos valores de UFC. 


\section{Referências}

1. Berk WA, Welch RD, Bock BF. Controversial issues in clinical management of the simple wound. Ann Emerg Med 1992; 21:72-80.

2. Burke FJT, Wilson NHF. Non-sterile glove use: a review. Am J Dent 1989; 2: 255-61.

3. Burke FJT. Use of non-sterile gloves in clinical practice. J Dent 1990; 18: 79-89.

4. Giglio JA, Rowland R W, Laskin DM, et al. The use of sterile versus nonsterile gloves during out-patient exodontia. Quintessence Int 1995; 26: 533-34.
5. Rossoff $L$, et al. Is the use of boxed gloves in an intensive care unit safe? Am J Med 1993; 94: 602-07.

6. Sadowski DA, et al. Use of no sterile gloves for routine invasive procedures in thermally injured patients. J Burn Care Rehabil 1988; 9: 613-15.

\section{Nota}

Tese de Doutorado defendida em 19/10/2007. 
